\title{
Eco-Friendly Selection of Diesel Generator Based on Genset-Synchro Technology for Off-Grid Remote Area Application in the North of Quebec
}

\author{
Mohamad Issa*, Jean Fiset, Hussein Ibrahim, Adrian Ilinca \\ Department of Mathematics, Informatics and Engineering, Université du Québec à Rimouski, Rimouski, Canada \\ Email: *missa@imq.qc.ca
}

How to cite this paper: Issa, M., Fiset, J., Ibrahim, H. and Ilinca, A. (2019) Eco-Friendly Selection of Diesel Generator Based on Genset-Synchro Technology for Off-Grid Remote Area Application in the North of Quebec. Energy and Power Engineering, 11, 232-247.

https://doi.org/10.4236/epe.2019.115015

Received: May 5, 2019

Accepted: May 28, 2019

Published: May 31, 2019

Copyright $\odot 2019$ by author(s) and Scientific Research Publishing Inc. This work is licensed under the Creative Commons Attribution-NonCommercial International License (CC BY-NC 4.0). http://creativecommons.org/licenses/by-nc/4.0/ (c) (i) \& Open Access

\begin{abstract}
For most of their energy requirements, greater part of remote communities and small islands around the world rely on imported fossil fuels. The economical cost of energy is therefore very high not only due to inherent cost of fuel, but also due to transportation and due to maintenance costs. One solution for saving fuel in a diesel generator is to allow the engine to operate directly in relation to the request for electrical load at variable speeds. Genset-Synchro Technology has developed an innovative variable speed generator technology (patent pending) that allows applications where power demand varies widely to benefit from the new technology that maintains constant voltage and frequency while adjusting the generator stator speed to power demand. This paper will present an innovative approach for optimizing the energy production based from the fact that the structure that contains the stator windings of the generator is mounted on roller bearings, which allows its free rotation around the axis of the rotor, consequently stopping the stator structure from being static and aims to minimize the unit cost of electricity. Case study on application in remote area in the north of Quebec is described. A saving of 7\% - 9\% on fuel consumption and greenhouse gas (GHG) under low winter ambient temperatures has been registered.
\end{abstract}

\section{Keywords}

Diesel Generator, Remote Areas, Fuel Saving, Greenhouse Gas, Electrical Machines, Control of Rotor Speed, Variable Diesel Speed Generator, Total Distortion Harmonics 


\section{Introduction}

Most remote and isolated communities or technical facilities (communication relays, meteorological systems, tourist facilities, farms, etc.) not connected to national electrical grids rely on diesel generators to generate electricity [1]. About 200,000 people in Canada live in more than 300 remote communities (Yukon, Northwest Territories, Nunavut, etc.) that use diesel-generated electricity, which is responsible for the annual emission of 1.2 million tons of greenhouse gases (GHGs) [2]. There are more than 14,000 subscribers scattered in about 40 communities in Quebec that are not connected to the main electrical grid. Each community is an autonomous network using diesel generators to generate electricity [3]. The diesel generating units, while requiring relatively little investment, are generally expensive to operate and maintain, especially when operating at partial load on a regular basis [4]. Under weak operating factors, the use of diesel power generators accelerates wear and increases fuel consumption [5].

Over the past few years, oil prices have reached historic highs, peaking at \$147/barrel in July 2008, averaging over \$100/barrel in 2011, averaging over $\$ 110 /$ barrel by October 2014, then falling to $\$ 80 /$ barrel. Recently, the oil price is around 69 $\$ /$ barrel. Despite this significant drop, diesel fuel prices in some provinces in Canada are losing just a few cents. According to statistic Canada, in St. John's Newfoundland, the diesel fuel lost only $5.7 \mathrm{\$} / \mathrm{L}$, and in Whitehorse in Yukon is increased by $3.5 / \mathrm{L}$ and in Yellowknife in Northwest Territories is set to rise up to $9.3 \mathrm{\Phi} / \mathrm{L}$ in October 2014 compared to 2013. According to Statistics Canada (http://www5.statcan.gc.ca), the decline in crude oil prices is not felt at the pump in this region. However, the pump price gasoline only decreased by 11.8 C/L from a high of $\$ 112$ per barrel to a low of $\$ 35$ per barrel in December 2015. Therefore, the decrease in oil prices has not greatly affected the price of diesel fuel, which implies that the electrical energy produced using only oil as energy source will always remain expensive, at any cost of barrel [6]. According to Hydro Quebec, extending the main grid to these isolated areas will cost around ( $1 \mathrm{M} \$ / \mathrm{km})$, which is impossible to do with the actual economic instability. Classic diesel generators are equipped with synchronous generators based on internal combustion engines; therefore, fixed speed operation is necessary. During low load operations, they operate inefficiently, Figure 1 [7].

In emergency power applications, it is not critical, but very important in continuously operated systems, where fuel consumption is an important economic and logistical aspect. Indeed, remote areas with relatively small communities generally show considerable variation between peak load time and minimum load time [8]. A typical example of a remote community's load profile in northern Quebec is shown in Figure 2.

In our project, we investigate another possibility that, when coupled to a DG operating in power unit, Figure 3, the Genset-Synchro alternator can operate at variable speeds without the need for costly power electronics components to generate a constant frequency on the terminals of the generator. The system can 


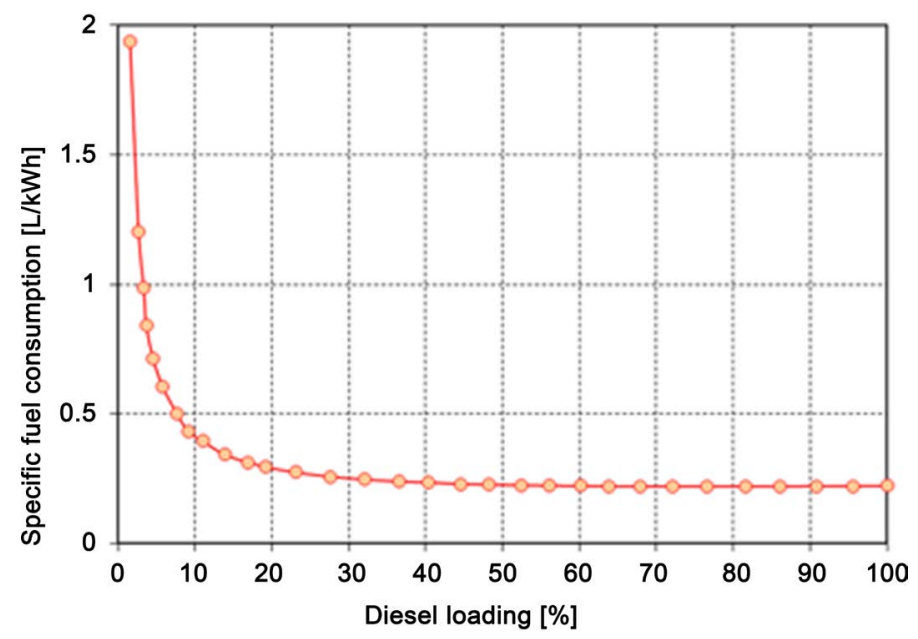

Figure 1. Example of diesel fuel consumption variation Vs loading [7].

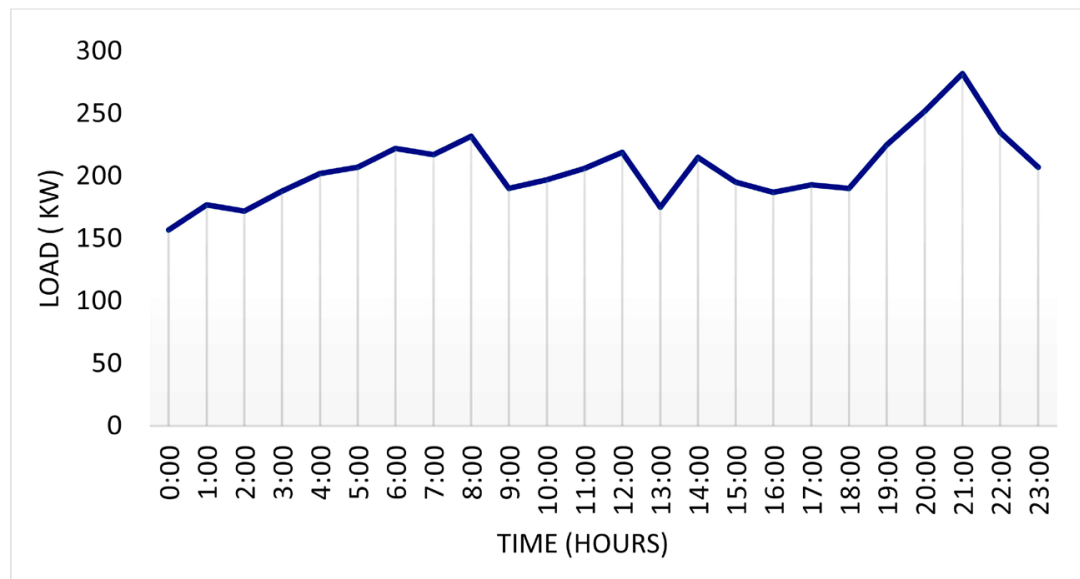

Figure 2. Example of a remote community's load profile at James Bay in the northwestern Quebec.

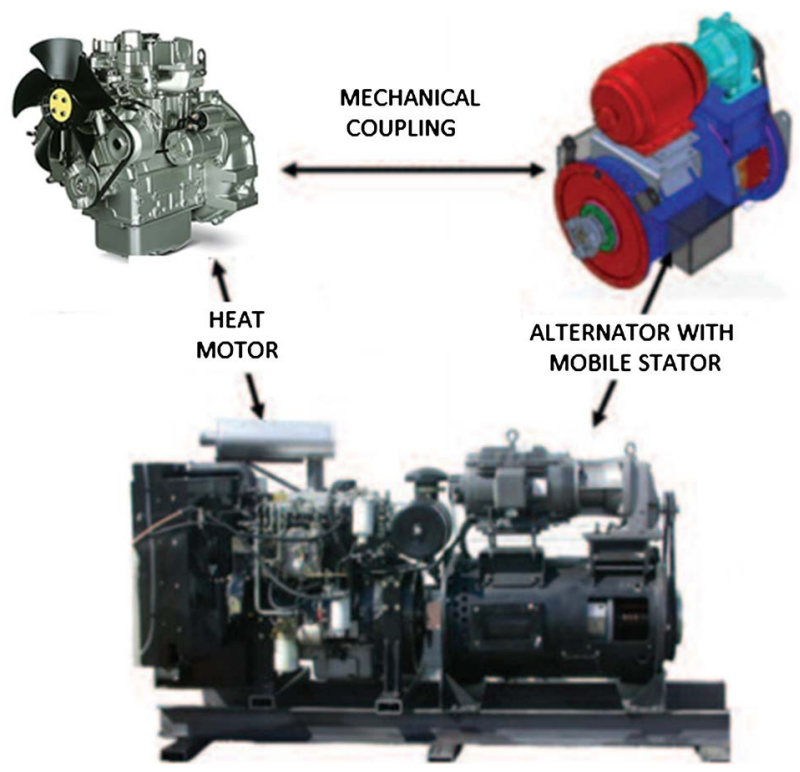

Figure 3. Illustration of the Genset-Synchro concept coupled to the diesel engine (DE). 
compensate for a lower or higher heat motor speed without disturbing the wave quality of the generated electricity. The project was developed by Concept Fiset Inc. and was performed by Rimouski University of Quebec's project partners. The Genset-Synchro concept has two international patents, including Canada the US [9] [10].

The objective of this study is to demonstrate that the Genset-Synchro concept can reduce the fuel consumption and the GHGs when applied to a diesel generator (DG). The structure of the present article is as follows. Section 2 presents the design approach of the Genset Synchro and its principal control. In Section 3 we present the bench test and the profile of the remote area in the northwestern Quebec. Section 4 presents the case study and we discuss the results obtained in order to demonstrate the efficiency of the Genset-Synchro technology for DG applications. Finally, in Section 5, we provide a preliminary conclusion and a perspective for the future work.

\section{The Design Approach of the Genset-Synchro Alternator}

The Genset-Synchro approach is a power unit control system based on new alternator design with a highly original concept to power generation. Changes to the structure holding the stator windings are the guiding principle behind the Genset-Synchro application where this structure now rotates freely in relation to the rotor and frame. An additional motor driven by a dedicated automatic controller assign the speed, desired position or acceleration of the stator structure. The concept ensures regular wave quality irrespective of rotor speed variations. As in conventional technologies, no energy passes through electronic equipment.

A synchronous alternator transforms the mechanical energy from a diesel engine into electrical energy to generate electricity in a power unit [11]. When this alternator integrates the concept of Genset-Synchro, the synchronous speed can remain constant by:

- Control of rotor speed only (existing design).

- Control of stator speed only (new design) [9] [10] [11].

- Control of both speeds simultaneously (new design) [9] [10] [11].

With the Genset-Synchro concept, the synchronous speed of a three-phase alternator can be controlled by controlling the stator's mechanical speed. Furthermore, since the Genset-Synchro is completely independent of the drive mechanism, it can be adapted to any type of rotor speed control and integrated into any type of power generation unit such as wind turbine, hydraulic turbine and gas turbine, etc. Figure 4 shows a prototype of the Genset-Synchro alternator with the main system components.

The electrical machine (compensating motor) is firmly fixed in an enclosure attached to the top of the synchronous motor enclosure using assembly means consisting of brackets and bolts such that the electrical machine's output shaft is aligned in parallel with the stator shaft. The electrical machine's output shaft and the stator shaft are connected by means of a timing belt and pulleys. The pri- 
mary pulley is fitted to the distal end of the stator shaft reaching outside the synchronous alternator enclosure and the top pulley is adapted to the electrical machine's output shaft so that both pulleys are aligned vertically. The timing belt links the two pulleys for one to drive the other. In Figure 5, the controlling unit receives an encoder feedback signal that senses the stator's position or velocity. In this case, the encoder is placed on the rotor to detect the rotor's position, and thus the speed. Additionally, the controlling unit refers to the produced alternating current as a feedback. According to the feedback signal, the controlling unit creates a control signal which is inputted to a variable speed drive in order to control the speed rotation of the electric machine and thereby the speed of the stator.

For example, the controller can be supplied as a programmable logic controller, a computer or any other processing unit. Typically, the variable speed drive is powered by the alternator's electrical current and the frequency regulation consumes part of the power produced. By controlling the rotation of the stator

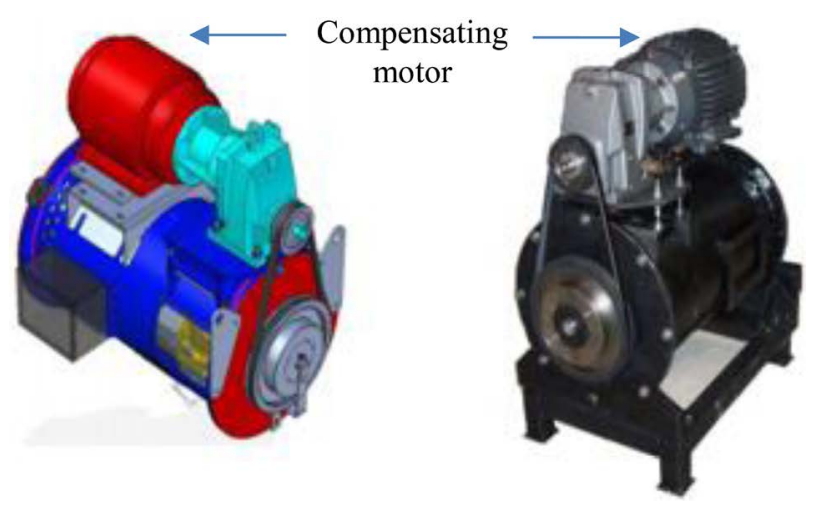

Figure 4. A perspective view of the Genset-Synchro alternator rated at $80 \mathrm{Kw}$.

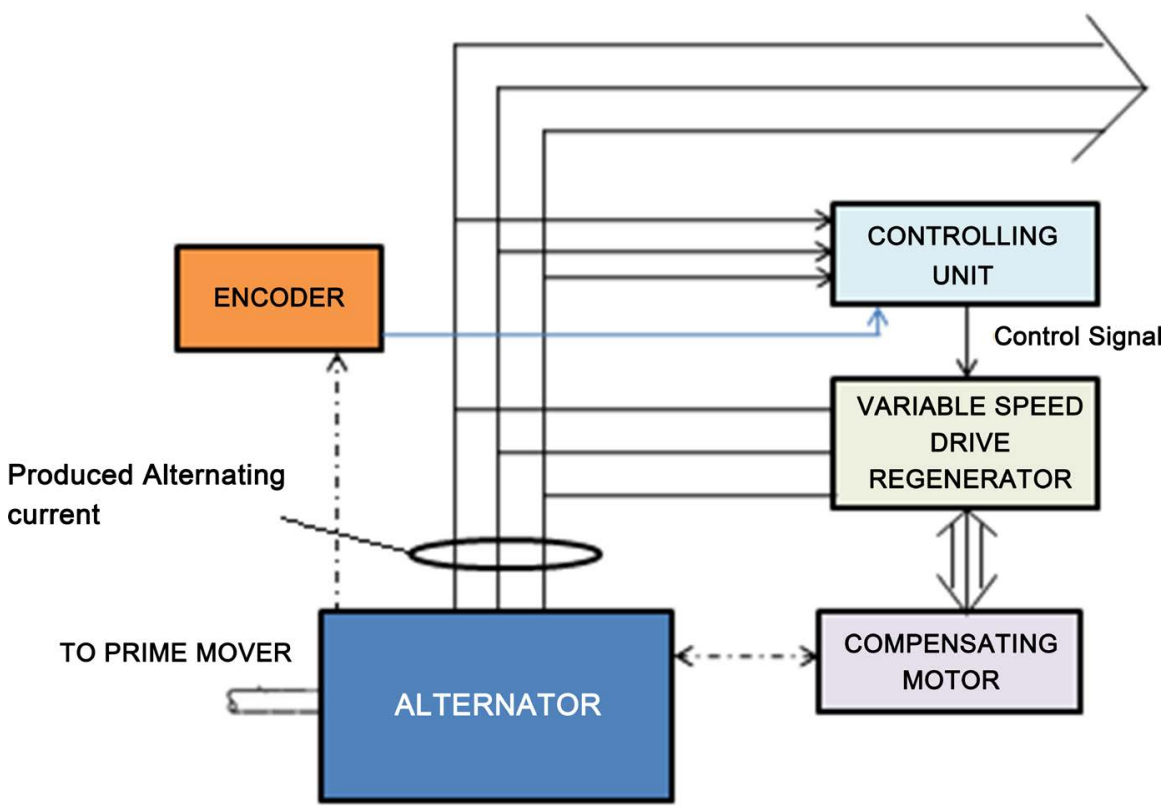

Figure 5. A system for electrical generation with a regulated frequency. 
about the rotor, the relative speed, and thereby the frequency of the generated electric current, can be regulated. For instance, a $60 \mathrm{~Hz}$ alternating current is generated in a typical wind turbine generator in a four-pole three-phase alternator rotating at 1800 RPM. The speed of the prime mover, i.e. the wind turbine, can rotate faster when the wind is strong, for instance at $2000 \mathrm{RPM}$. Then, the stator is rotated at 200 RPM in the direction of rotation of the rotor to compensate for such a higher rotation speed of the rotor. The relative speed between the rotor and the stator is thus 1800 RPM (2000 RPM - 200 RPM: 1800 RPM). If, for example, the velocity of the rotor decreases due to weak winds, e.g. at 1500 RPM, the stator rotates in the opposite direction to the rotor at 300 RPM.

\section{Genset-Synchro Application for Power Units: Description of the Test Bench}

Figure 6 shows the schematic of the test bench, while Figure 7 shows the unit employed in the remote communities at James Bay in the northwestern Quebec.

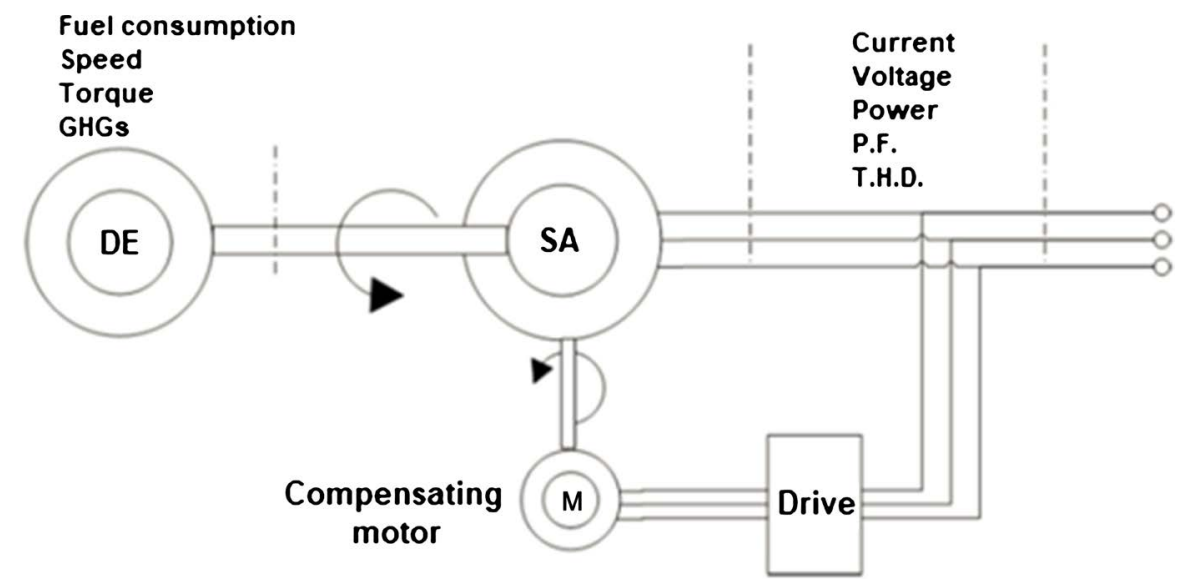

Figure 6. Schematic of the bench test.

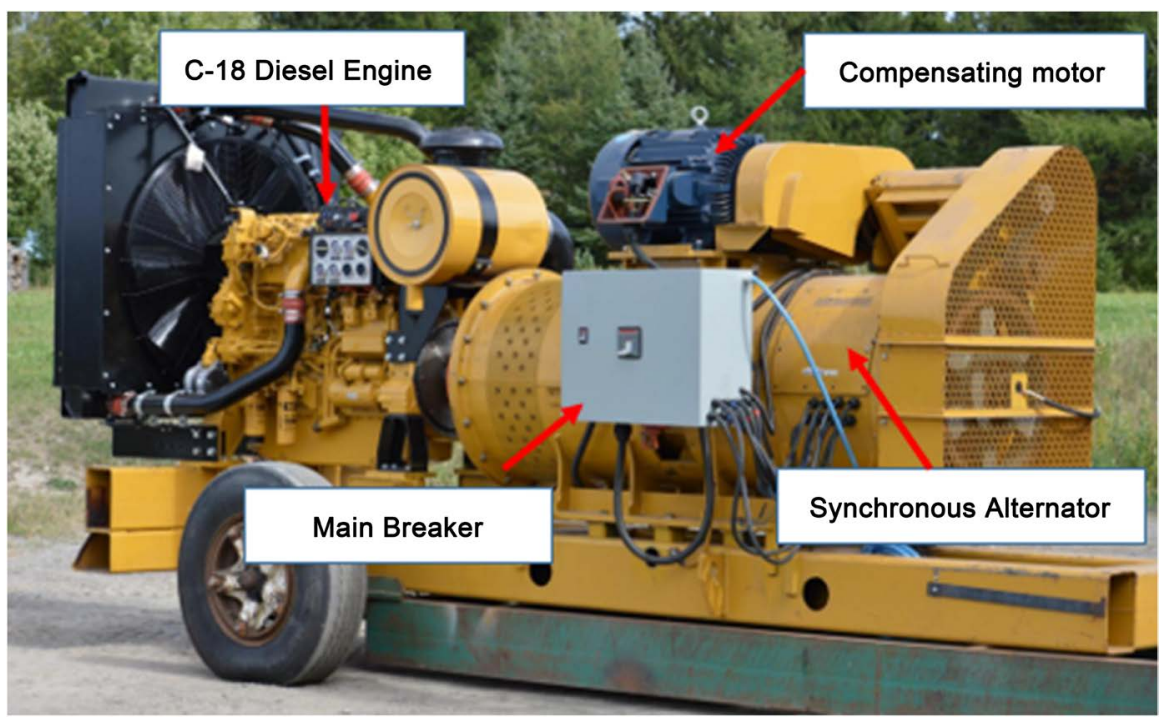

Figure 7. Illustration of the Genset-Synchro GS500X unit with the main components. 
It consists of an $800 \mathrm{hp}$ diesel engine (C-18 model Tier III from Caterpillar) as a prime mover coupled to a synchronous alternator of $575 \mathrm{~kW}$ (made by the French company Le Roy Somer). A compensating motor (100 hp) provides the necessary rotation speed of the synchronous alternator stator fixed on the top of the alternator and coupled to a three-phase drive. The diesel engine was instrumented by a differential flowmeter with a torque sensor and speed sensor, while the output of the synchronous alternator was instrumented with a power analyzer, Figure 8. Moreover, a combustion flue gas analyzer (Testo 350) was used to evaluate the impact of the Genset-Synchro technology in GHGs emissions.

\section{Description of the Remote Communities}

Highway 381 is a rest stop on the James Bay Highway in northwestern Quebec, Figure 9. It includes buildings including a hotel, a cafeteria, garages, a service

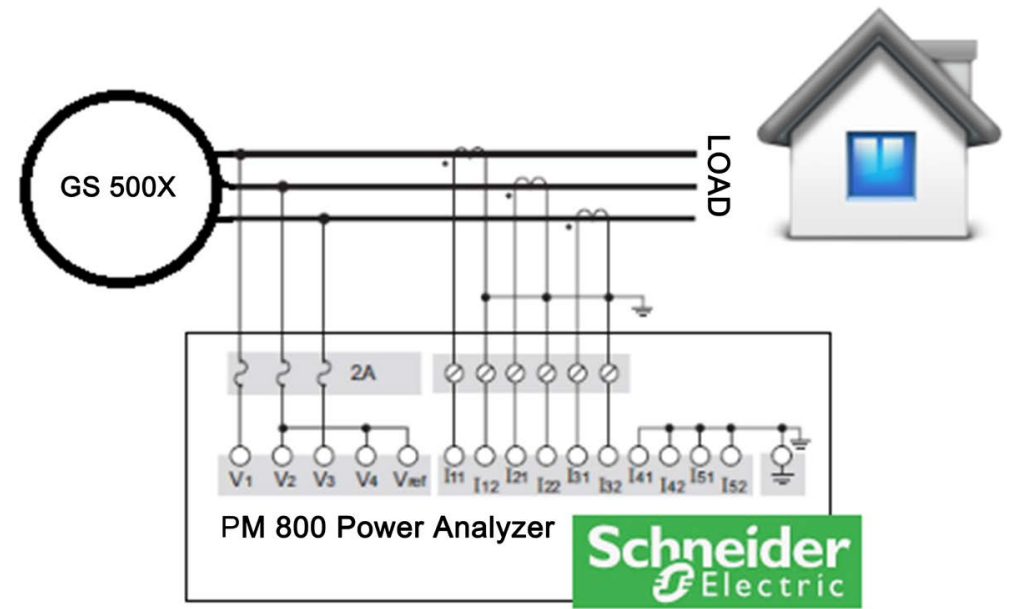

Figure 8. Connection of the power analyzer to the GS-500X output.
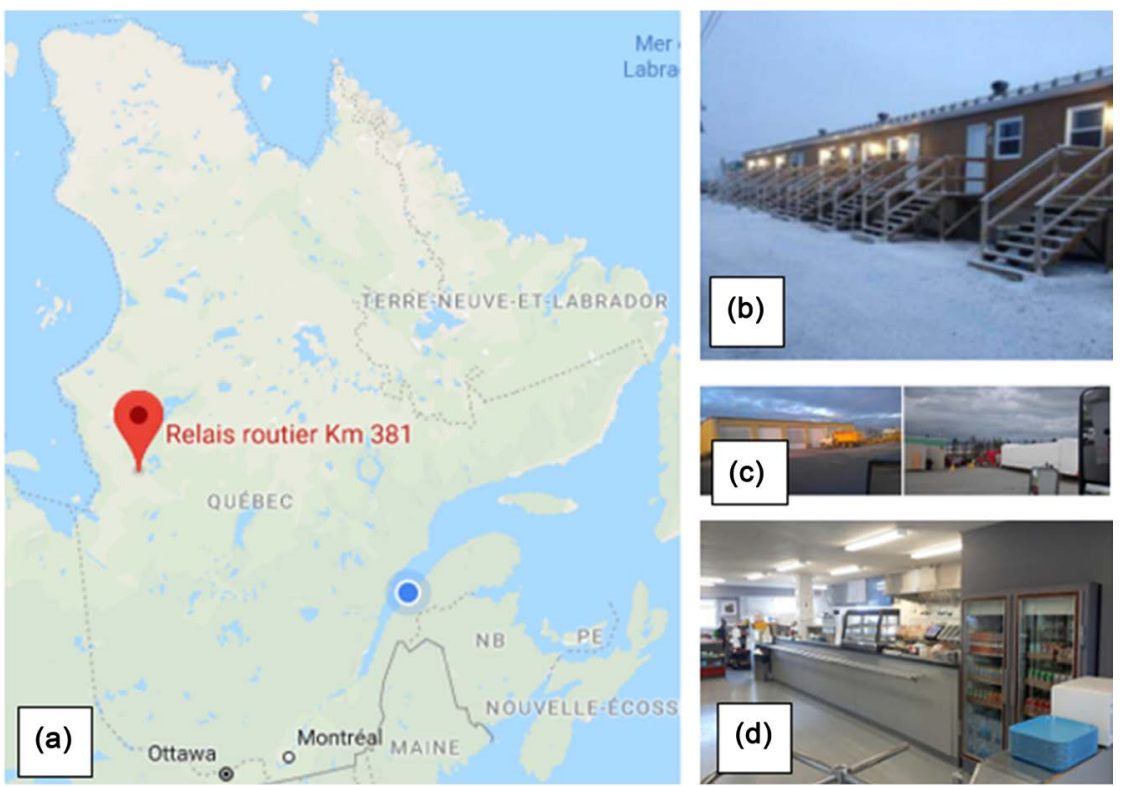

Figure 9. (a) Site location for the roadstop km 381; (b) The hotel; (c) Garages and Service Station; (d) The Cafeteria (Source: google map). 
station, houses for Hydro-Québec and a visitor's pavilion. The relay is an Off-grid site. Its power comes from diesel generators only.

According to the technical report issued by the Ministry of Energy and Natural Resources in 2015 [12] regarding the roadstop $\mathrm{km} \mathrm{381,} \mathrm{the} \mathrm{diesel} \mathrm{fuel} \mathrm{con-}$ sumption for the year 2015 is $362,275 \mathrm{~L}$ representing the equivalent of 1011 tonnes of $\mathrm{CO}_{2}$ emissions.

In order to minimize fuel consumption, GHG emissions and reduce the environmental impact of emissions, it has been proposed to replace diesel generators with electrical equipment (extension of the electricity network). While waiting for the project to be adopted and financed, it has been proposed to ensure the electrification of the site by the GS500X unit from Genset-Synchro Technology which, has demonstrated on a prototype of $500 \mathrm{~kW}$ fuel savings by mean of $12 \%$ [13].

\section{Discussion}

Roadstop's $\mathrm{km} 381$ location is characterized by extremely cold winter temperatures that reach $-30^{\circ} \mathrm{C}$ during the months of January and February. In this section, recorded data are intended to evaluate the performance of the GS500X unit under low registered temperatures with three different stator speed. Attention is given to fuel consumption, GHGs emission and for the total harmonic distortion (THD) at the output of the generator. To do, the standard IEEE-519-2014 is considered as reference [14].

\subsection{Fuel Consumption Analysis}

Since the Caterpillar C-18 Tier III diesel consumption curve was determined with an ambient temperature of $16^{\circ} \mathrm{C}$ (according to the manufacturer manual), it was necessary to redefine this consumption curve in a cold climate to better identify the impact of Genset-synchro technology compared to the standard Genset mode under the same weather conditions. To do this, the generator was employed in standard mode (fixed stator) during the day of February 2019 for 24 hours without interruptions. The recorded data (the longest in terms of operation) are shown in Table 1 including the minimum and maximum recorded ambient temperatures.

According to Table 1, the fuel consumption is higher than that defined by the manufacturer by $9.5 \%$, (according to the manual owner). This can be explained by the fact that low temperatures have an impact on the density of the fuel (for

Table 1. Data recorded for the day of February 1, 2019. The maximum recorded ambient temperature is $-18^{\circ} \mathrm{C}$ and the minimum is $-27.1^{\circ} \mathrm{C}$.

\begin{tabular}{ccccc}
\hline Duration (hr.) & Load (kW) & Load (\%) & Engine Speed (RPM) & Fuel consumption (gr./kWh) \\
\hline 6 & 164 & 27.3 & 1800 & 267 \\
5 & 189 & 31.5 & 1800 & 254.2 \\
4.75 & 232 & 38.6 & 1800 & 248.8 \\
3.25 & 278 & 46.3 & 1800 & 239.6 \\
\hline
\end{tabular}


our tests-fuel density adjusted is $0.80729 \mathrm{~kg} /$ liter at $\left.15^{\circ} \mathrm{C}\right)$. Moreover, heat, cold oil and other fluids have a greater effect on fuel economy when the generator is used at less than optimal temperatures. Figure 10 shows a comparison of fuel consumption at $+15^{\circ} \mathrm{C}$ (according to the Caterpillar fuel consumption curve) and $-22^{\circ} \mathrm{C}$ for the same DG.

\subsection{Effect of the Genset-Synchro Technology on Fuel Consumption}

In this section, the results of DG fuel consumption with the mobile stator for February 10, Mars 19 and April 9 are presented. For the day of February 10, the speed of the diesel engine (DE) is set at $1520 \mathrm{rpm}$ and the stator at $280 \mathrm{rpm}$, while for the day of Mars 19, the speed of the DE is set at $1460 \mathrm{rpm}$ and the stator at $340 \mathrm{rpm}$ and finally, for the day of April 9, the speed of the DE is set at $1385 \mathrm{rpm}$ and the stator at $415 \mathrm{rpm}$. Tables 2-4 show the recorded data including the minimum and maximum registered temperatures.

In order to clearly distinguish the effect of the Genset-Synchro Technology on fuel consumption, a comparison was made considering the variation of the stator speed. Figure 11 shows the comparison of the fuel consumption for the three different speeds.

According to Figure 11, it can be seen that Genset-Synchro Technology achieve

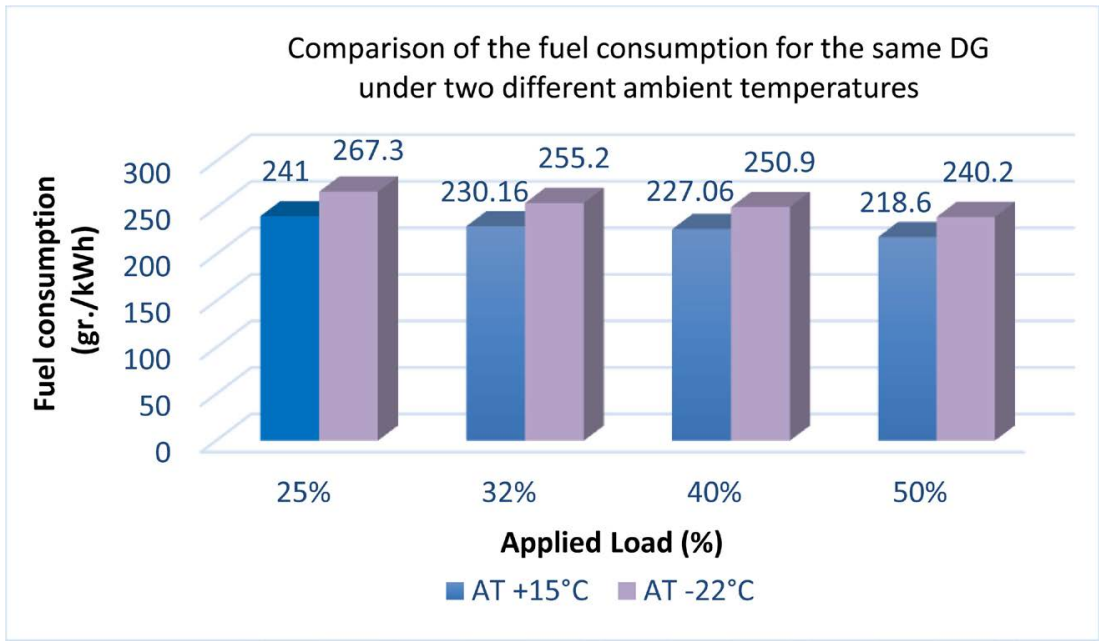

Figure 10. Evaluation and comparison of the C-18 Tier III fuel consumption at $+15^{\circ} \mathrm{C}$ Vs $-22^{\circ} \mathrm{C}$. An increase of $9.5 \%$ was recorded.

Table 2. Data recorded for the day of February 10, 2019. The maximum recorded ambient temperature is $-20^{\circ} \mathrm{C}$ and the minimum is $-31^{\circ} \mathrm{C}$.

\begin{tabular}{cccccc}
\hline $\begin{array}{c}\text { Duration } \\
(\mathrm{hr})\end{array}$ & $\begin{array}{c}\text { Load } \\
(\mathrm{kW})\end{array}$ & $\begin{array}{c}\text { Load } \\
(\%)\end{array}$ & $\begin{array}{c}\text { Engine Speed } \\
(\mathrm{RPM})\end{array}$ & $\begin{array}{c}\text { Stator Speed } \\
(\mathrm{RPM})\end{array}$ & $\begin{array}{c}\text { Fuel consumption } \\
(\mathrm{gr} / \mathrm{kWh})\end{array}$ \\
\hline 6.5 & 164 & 27.3 & 1520 & 280 & 250.1 \\
5 & 189 & 31.5 & 1520 & 280 & 242.1 \\
5.5 & 232 & 38.6 & 1520 & 280 & 237.2 \\
2.25 & 278 & 46.3 & 1520 & 280 & 226.6 \\
\hline
\end{tabular}


Table 3. Data recorded for the day of Mars 18, 2019. The maximum recorded ambient temperature is $-10^{\circ} \mathrm{C}$ and the minimum is $-21^{\circ} \mathrm{C}$.

\begin{tabular}{cccccc}
\hline $\begin{array}{c}\text { Duration } \\
(\mathrm{hr} .)\end{array}$ & $\begin{array}{c}\text { Load } \\
(\mathrm{kW})\end{array}$ & $\begin{array}{c}\text { Load } \\
(\%)\end{array}$ & $\begin{array}{c}\text { Engine Speed } \\
(\mathrm{RPM})\end{array}$ & $\begin{array}{c}\text { Stator Speed } \\
(\mathrm{RPM})\end{array}$ & $\begin{array}{c}\text { Fuel consumption } \\
\text { (gr./kWh) }\end{array}$ \\
\hline 6.3 & 164 & 27.3 & 1460 & 340 & 244.6 \\
4.8 & 189 & 31.5 & 1460 & 340 & 240.1 \\
4.5 & 232 & 38.6 & 1460 & 340 & 231.7 \\
3.25 & 278 & 46.3 & 1460 & 340 & 222.4 \\
\hline
\end{tabular}

Table 4. Data recorded for the day of April 9, 2019. The maximum recorded ambient temperature is $-7^{\circ} \mathrm{C}$ and the minimum is $-10^{\circ} \mathrm{C}$.

\begin{tabular}{cccccc}
\hline $\begin{array}{c}\text { Duration } \\
(\mathrm{hr} .)\end{array}$ & $\begin{array}{c}\text { Load } \\
(\mathrm{kW})\end{array}$ & $\begin{array}{c}\text { Load } \\
(\%)\end{array}$ & $\begin{array}{c}\text { Engine Speed } \\
(\mathrm{RPM})\end{array}$ & $\begin{array}{c}\text { Stator Speed } \\
(\mathrm{RPM})\end{array}$ & $\begin{array}{c}\text { Fuel consumption } \\
(\mathrm{gr} . / \mathrm{kWh})\end{array}$ \\
\hline 6.3 & 164 & 27.3 & 1385 & 415 & 240.2 \\
4.8 & 189 & 31.5 & 1385 & 415 & 237.8 \\
4.5 & 232 & 38.6 & 1385 & 415 & 228.7 \\
3.25 & 278 & 46.3 & 1385 & 415 & 218.1 \\
\hline
\end{tabular}

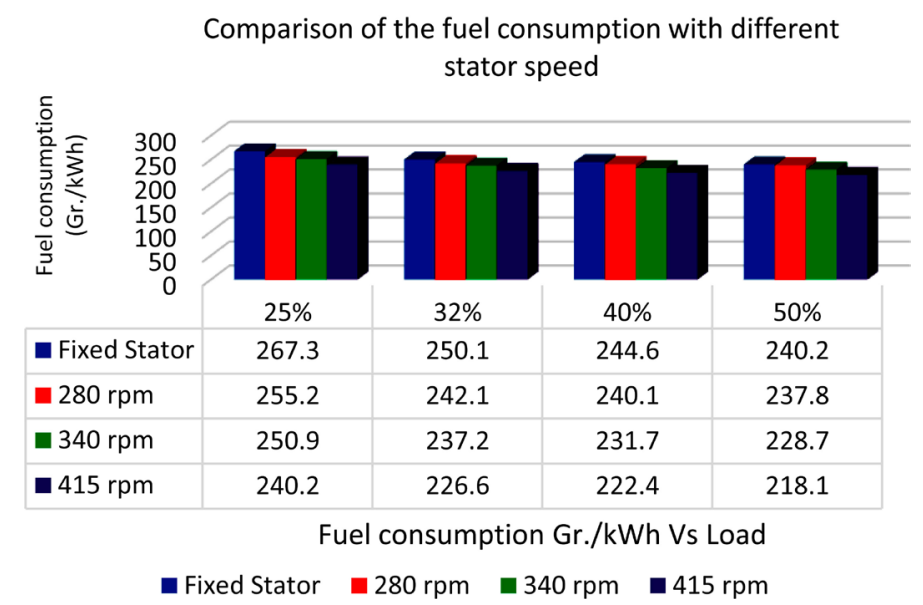

Figure 11. Comparison of the fuel consumption with different stator speed Vs fixed stator under low and medium loads.

the best economy when stator is employed at $415 \mathrm{rpm}$ with an average of 22.2 grams $/ \mathrm{kWh}$, while this saving decreases for $18.5 \mathrm{grams} / \mathrm{kWh}$ when stator is employed at $340 \mathrm{rpm}$ and to $13.3 \mathrm{grams} / \mathrm{kWh}$ when stator is employed at $280 \mathrm{rpm}$.

\subsection{Effect of the Genset-Synchro Technology on Greenhouse Gases (GHGs)}

Emissions from diesel engine contribute to divers cardiovascular and respiratory diseases and cancer, in addition to water and soil pollution, visibility reductions and global climates changes [15] [16] [17]. In this context, we evaluate the GHG emissions emitted by the DE with the fixed stator and with the Genset-Synchro concept. To do, combustion analyzer (Testo 350) is used to evaluate the carbon 
dioxide $\left(\mathrm{CO}_{2}\right)$, sulfur oxide $\left(\mathrm{SO}_{\mathrm{x}}\right)$, nitrogen oxide $\left(\mathrm{NO}_{\mathrm{x}}\right)$ and particulate matter (PM). We used number 2 diesel fuel type B-ULS with maximum fuel sulfur of 15 $\mathrm{mg} / \mathrm{kg}$. Table 5 shows the emissions rate when the DG is employed in standard mode (fixed stator) while Table 6 shows the emissions rate when DG use the Genset-Synchro concept. Given that the stator speed employed at $415 \mathrm{rpm}$ offers the best economy on fuel, we just take this speed into consideration for comparison purposes.

Based on the data registered on Table 5 and Table 6, it can be concluded that fuel economy achieved with the Genset-Synchro Technology has a positive impact on GHGs reduction. This impact is proportional to the amount of fuel saved. Table 7 shows the overall average of GHGs reduction when the stator is employed at $415 \mathrm{rpm}$.

\subsection{Effect of the Genset-Synchro Technology on the Total Harmonic Distortion (THD)}

THD is the measurement of electricity quality. Clean signal is considered good

Table 5. Data recorded concerning the GHG emissions when DG is employed with fixed stator.

\begin{tabular}{ccccccc}
\hline $\begin{array}{c}\text { Load } \\
(\mathrm{kW})\end{array}$ & $\begin{array}{c}\text { Engine Speed } \\
(\mathrm{RPM})\end{array}$ & $\begin{array}{c}\text { Fuel consumption } \\
(\mathrm{l} / \mathrm{h} .)\end{array}$ & $\begin{array}{c}\mathrm{CO}_{2} \\
(\mathrm{Kg})\end{array}$ & $\begin{array}{c}\mathrm{SO}_{\mathrm{x}} \\
(\mathrm{Kg})\end{array}$ & $\begin{array}{c}\mathrm{NO}_{\mathrm{x}} \\
(\mathrm{Kg})\end{array}$ & $\begin{array}{c}\mathrm{PM} \\
(\mathrm{Kg})\end{array}$ \\
\hline 164 & 1800 & 54.16 & 148.39 & 0.230 & 0.119 & 0.0054 \\
189 & 1800 & 59.56 & 163.19 & 0.253 & 0.131 & 0.0059 \\
232 & 1800 & 71.62 & 196.23 & 0.304 & 0.157 & 0.0071 \\
278 & 1800 & 82.51 & 226.07 & 0.351 & 0.181 & 0.008 \\
\hline
\end{tabular}

Table 6. Data recorded concerning the GHG emissions when DG is employed with a stator speed of $415 \mathrm{rpm}$.

\begin{tabular}{ccccccc}
\hline $\begin{array}{c}\text { Load } \\
(\mathrm{kW})\end{array}$ & $\begin{array}{c}\text { Engine Speed } \\
(\mathrm{RPM})\end{array}$ & $\begin{array}{c}\text { Fuel consumption } \\
(\mathrm{l} / \mathrm{h} .)\end{array}$ & $\begin{array}{c}\mathrm{CO}_{2} \\
(\mathrm{Kg})\end{array}$ & $\begin{array}{c}\mathrm{SO}_{\mathrm{x}} \\
(\mathrm{Kg})\end{array}$ & $\begin{array}{c}\mathrm{NO}_{\mathrm{x}} \\
(\mathrm{Kg})\end{array}$ & $\begin{array}{c}\mathrm{PM} \\
(\mathrm{Kg})\end{array}$ \\
\hline 164 & 1385 & 49.20 & 134.80 & 0.209 & 0.108 & 0.0049 \\
189 & 1385 & 55.67 & 152.53 & 0.237 & 0.122 & 0.0055 \\
232 & 1385 & 65.72 & 180.07 & 0.279 & 0.144 & 0.0065 \\
278 & 1385 & 75.10 & 205.77 & 0.319 & 0.165 & 0.0075 \\
\hline
\end{tabular}

Table 7. Overall average of GHG's reduction with a stator speed of $415 \mathrm{rpm}$.

\begin{tabular}{ccccc}
\hline \multirow{2}{*}{ Load (kW) } & \multicolumn{4}{c}{ Difference of the reduction (\%) } \\
\cline { 2 - 5 } & $\mathrm{CO}_{2}$ & $\mathrm{SO}_{\mathrm{x}}$ & $\mathrm{NO}_{\mathrm{x}}$ & $\mathrm{PM}$ \\
\hline 164 & $10.08 \%$ & $10.04 \%$ & $10.18 \%$ & $10.2 \%$ \\
189 & $6.98 \%$ & $6.75 \%$ & $7.37 \%$ & $7.27 \%$ \\
232 & $8.97 \%$ & $8.96 \%$ & $9.02 \%$ & $9.23 \%$ \\
278 & $9.86 \%$ & $10.03 \%$ & $9.69 \%$ & $6.66 \%$ \\
Average & $8.97 \%$ & $8.94 \%$ & $9.065 \%$ & $8.34 \%$ \\
\hline
\end{tabular}


with a THD of less than of $6 \%$ and is frequently declared or promoted at $5 \%$ or less [18]. Higher heating due to iron and copper losses at the harmonic frequencies is a major effect of harmonic voltages and currents in rotating machines (induction and synchronous). Moreover, according to [19], THD can increase by an amount of $2 \%$ due to the effect of vibration. In order to properly evaluate the effect of the Genset-Synchro concept on the signal quality at the output of the alternator, we have referred to the IEEE-519-2014 standard (Recommended practice and requirements for harmonic control in electric power systems). A power analyzer PM800 from Schneider electric is used, Figure 8. On the other hand, it was important to know the current and voltage distortion limits for our system. Based on IEEE-519 standard, Table 8 and Table 9 show the current and voltage distortion limits for systems rated $120 \mathrm{~V}$ through $69 \mathrm{kV}$.

In order to refer to the right limit, we referred to the manual manufacturer for a C-18 diesel generator defined by Caterpillar for 3 phases, $600 \mathrm{~V}, 575 \mathrm{~kW}$. Short circuit current is limited to $300 \% / 10$ sec. which represents a TDD limit of $15 \%$ and a voltage distortion limit of $8 \%$.

In this context, we measured the THD limits in current and voltage with the conventional mode (fixed stator) for the purpose of comparing them later with the Genset-Synchro mode. Table 10 illustrates the THD limits in current and voltage for the conventional mode, while Table 11 illustrates the THD limits in current and voltage when the stator is employed at $415 \mathrm{rpm}$.

Based on our results, the Genset-Synchro mode shows an increase in the current and voltage harmonics level versus conventional mode. However, in order to confirms if the speed employed has an impact on the level of vibration and on the THD, we analyzed the recorded measurements when the speed of the stator

Table 8. Current distortion limits for systems rated $120 \mathrm{~V}-69 \mathrm{Kv}$ [14].

\begin{tabular}{cc}
\hline Short-circuit current & Total demand distortion (TDD) limit \\
\hline load current & $5 \%$ \\
\hline$<20$ & $8 \%$ \\
$20-50$ & $12 \%$ \\
$50-100$ & $15 \%$ \\
$100-1000$ & $20 \%$ \\
$>1000$ & \\
\hline
\end{tabular}

Table 9. Voltage distortion limits [15] and [19].

\begin{tabular}{ccc}
\hline Bus voltage at PCC $^{*}$ & Individual harmonic (\%) & THD limit \\
\hline $\mathrm{V} \leq 1.0 \mathrm{kV}$ & 5.0 & $8 \%$ \\
$1 \mathrm{kV}<\mathrm{V} \leq 69 \mathrm{kV}$ & 3.0 & $5 \%$ \\
$69 \mathrm{kV}<\mathrm{V} \leq 161 \mathrm{kV}$ & 1.5 & $2.5 \%$ \\
$161 \mathrm{kV}<\mathrm{V}$ & 1.0 & $1.5 \%$ \\
\hline
\end{tabular}

PCC: Point of Common Coupling. 
used was at $280 \mathrm{rpm}$. Table 12 shows the recorded results with a stator speed of $280 \mathrm{rpm}$ and a power factor of 0.98 .

According to Tables 10-12, the stator speed has a negative impact on the THD level. This can be explained by the fact that as the stator speed increases, the vibration in the generator increases, affecting the THD level [20]. Figure 12

Table 10. Data recorded concerning the THD limits in current and voltage with the conventional mode (fixed stator) and a power factor of 0.98 .

\begin{tabular}{cccc}
\hline Load (kW) & Engine Speed (RPM) & Current THD (\%) & Voltage THD (\%) \\
\hline 164 & 1800 & 2.7 & 6.0 \\
189 & 1800 & 2.5 & 6.9 \\
232 & 1800 & 2.3 & 8.1 \\
278 & 1800 & 2.2 & 9.2 \\
\hline
\end{tabular}

Table 11. Data recorded concerning the THD limits in current and voltage with a stator speed of $415 \mathrm{rpm}$ and a power factor of 0.98 .

\begin{tabular}{cccc}
\hline Load (kW) & Engine Speed (RPM) & Current THD (\%) & Voltage THD (\%) \\
\hline 164 & 1385 & 3.0 & 7.6 \\
189 & 1385 & 2.7 & 8.5 \\
232 & 1385 & 2.5 & 9.8 \\
278 & 1385 & 2.3 & 11.4 \\
\hline
\end{tabular}

Table 12. Data recorded concerning the THD limits in current and voltage with a stator speed of $280 \mathrm{rpm}$ and a power factor of 0.98 .

\begin{tabular}{cccc}
\hline Load (kW) & Engine Speed (RPM) & Current THD (\%) & Voltage THD (\%) \\
\hline 164 & 1520 & 2.8 & 7.0 \\
189 & 1520 & 2.7 & 8.0 \\
232 & 1520 & 2.4 & 9.6 \\
278 & 1520 & 2.3 & 10.8 \\
\hline
\end{tabular}

Impact of the stator speed on THD current level

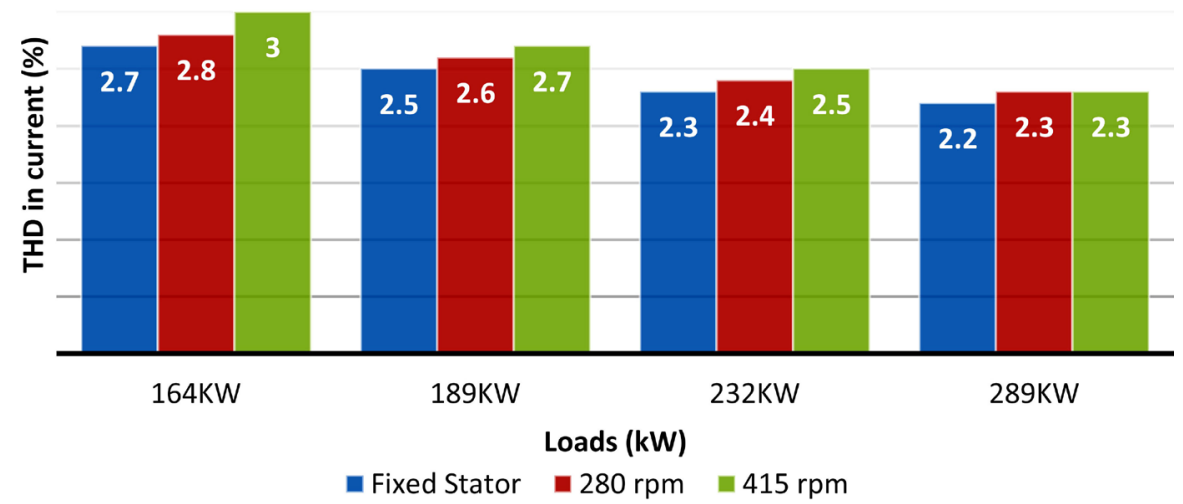

Figure 12. Comparison on the THD current level in relation to the stator speed. 
Impact of the stator speed on THD voltage level

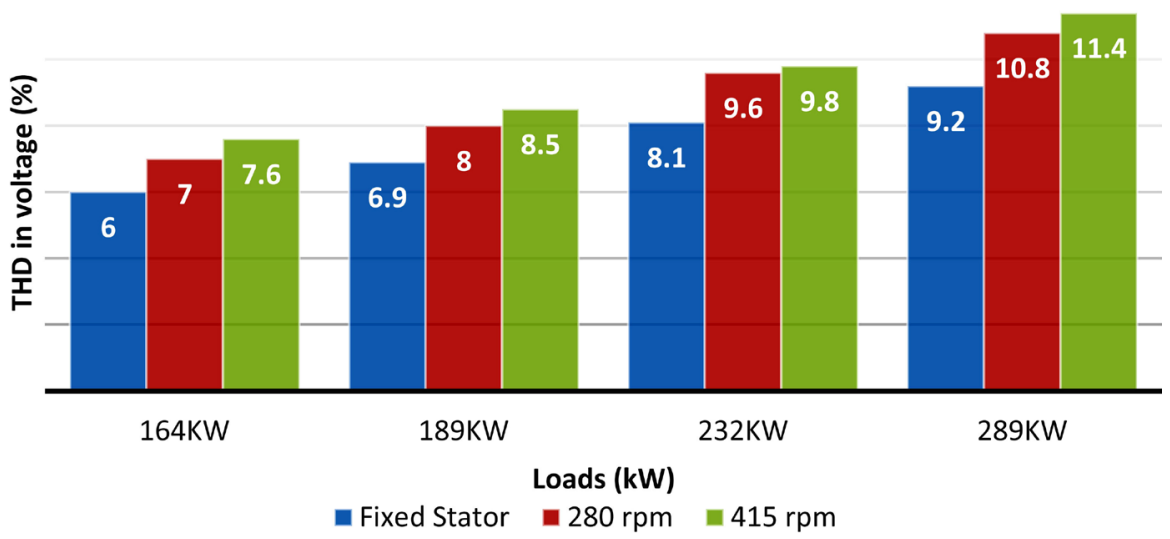

Figure 13. Comparison on the THD voltage level in relation to the stator speed.

and Figure 13 show the difference in the THD rates in relation to the stator speed.

According to the IEEE-519 standard, the Genset-Synchro GS500X respect the current distortion limits, while the voltage distortion limits is higher by $3.4 \%$ at $50 \%$ of load. However, the generator used is oversized for the site. For this reason, it was not possible to evaluate the THD levels for high applied loads $(>70 \%)$

\section{Conclusions}

This paper presents the innovative feature of the Genset-Synchro Technology which originate from a rotational non-fixed stator design and a fuel savings evaluation for a DG that can be achieved by controlling the rotation of the stator. The experimental results show that significant fuel savings of $7 \%-9 \%$ can be obtained at low power loads $\leq 45 \%$ which can be very attractive for isolated communities were most of the DGs frequently run under low loads $\leq 40 \%$. Furthermore, this fuel saving has reduced the level of GHGs by amount of $8 \%-9 \%$.

Despites these advantages, the voltage harmonic distortion rate proves to be higher when the Genset-Synchro mode is employed. It has also been found that as the stator speed increases the THD increases due to the vibrations. According to the IEEE-519-2014 standard, it is mandatory to install a filter at the output of the generator to ensure that the voltage distortion rate remains between $6 \%-9 \%$ for all applied loads. On the other hand, the current distortion rate is lightly higher when Genset-Synchro mode is employed. However, the level remains below $4 \%$ limit required by the IEEE-519-2014 standard.

Since the generator used at James Bay is oversized for the site, it was not possible to load more than $48 \%$ and to cover all loads range under less optimal temperatures for the operation of the generator. Nonetheless, the Genset-Synchro Technology is interesting (beneficial) to use in isolated sites whose access to the power grid is not possible and where the fuel deliveries are difficult during cold seasons. 
Based in our results, the fuel saving is projected to be $8 \%$ under low winter temperatures $\left(-7^{\circ} \mathrm{C}\right.$ to $\left.-30^{\circ} \mathrm{C}\right)$. For equivalent purposes, a $600 \mathrm{~kW} \mathrm{C}-18 \mathrm{DG}$ equipped by a Genset-Synchro alternator can achieve $6.8 \mathrm{l} / \mathrm{h}$ of fuel saving for a $50 \%$ applied load, which represents an annual fuel saving of 47,600 liters over 7000 hours of annual operation and $130,424 \mathrm{t} \mathrm{CO}_{2}$.

\section{Conflicts of Interest}

The authors declare no conflicts of interest regarding the publication of this paper.

\section{References}

[1] Ibrahim, H., Younes, R., Basbous, T., Ilinca, A. and Dimitrova, M. (2011) Optimization of Diesel Engine Performances for a Hybrid Wind-Diesel System with Compressed Air Energy Storage. Energy, 36, 3079-3091. https://doi.org/10.1016/j.energy.2011.02.053

[2] Li, C. and Yu, W. (2016) Techno-Economic Comparative Analysis of Off-Grid Hybrid Photovoltaic/Diesel/Battery and Photovoltaic/Battery Power Systems for a Household in Urumqi, China. Journal of Cleaner Production, 124, 258-265. https://doi.org/10.1016/j.jclepro.2016.03.002

[3] Ibrahim, H., Ilinca, A., Younes, R. and Basbous, T. (2007) Study of a Hybrid WindDiesel System with Compressed Air Energy Storage. Electrical Power Conference 2007, "Renewable and Alternative Energy Resources", Montreal, 25-25 October 2007, 320-325. https://doi.org/10.1109/EPC.2007.4520350

[4] Hunter, R. and Elliot, G. (1994) Wind-Diesel Systems-A Guide to the Technology and Its Implementation. Cambridge University Press, Cambridge. https://doi.org/10.1017/CBO9780511574467

[5] Forcione, A. (2004) Système jumelé éolien-Diesel aux îles-de-la-Madeleine (Cap-aux Meules) Établissement de la VAN optimale. Institut de Recherche, Hydro Québec, Février.

[6] Rezkallah, M. (2016) Design and Control of Standalone and Hybrid Standalone Power Generation Systems. Diss. École de technologie supérieure.

[7] Ibrahim, H. and Ilinca, A. (2012) Contribution of the Compressed Air Energy Storage in the Reduction of GHG-Case Study: Application on the Remote Area Power Supply System. Chapter 13, Intech, London. https://doi.org/10.5772/50131

[8] Pena, R., Cárdenas, R., Proboste, J., Clare, J. and Asher, G. (2008) Wind-Diesel Generation Using Doubly Fed Induction Machines. IEEE Transactions on Energy Conversion, 23, 202-214. https://doi.org/10.1109/TEC.2007.914681

[9] Jean, F. (2007) Canadian Intellectual Property Office-Patent No. 2697420: Mechanical Regulation of Electrical Frequency in an Electrical Generation System.

[10] Jean, F. and Durand, T. (2008) United States Patent \& Trademark Office-Patent No. US8258641B2: Mechanical Regulation of Electrical Frequency in an Electrical Generation System.

[11] Tiberiu, T. and Cristian, R. (2010) The Numerical Modeling of Transient Regimes of Diesel Generator Sets. Acta Polytechnica Hungarica, 7, 39-53.

[12] Ministère de l'énergie et des Ressources naturelles (2016) Extension de ligne pour le relais routier du km 381. Doc. No. ECO-20a-15-16-0422-0001, 2016-15-12.

[13] Mohammadjavad, M., Jean, F. and Adrian, I. (2017) Modeling and Optimization of 
the Energy Production Based on Eo-Synchro Application. Power Engineer, 3.

[14] 519-2014-IEEE Recommended Practice and Requirements for Harmonic Control in Electric Power Systems. https://ieeexplore.ieee.org/document/6826459

[15] James, M., Paul, C., et al. (2007) Respiratory Effects of Exposure to Diesel Traffic in Persons with Asthma. New England Journal of Medicine, 357, 2348-2358. https://doi.org/10.1056/NEJMoa071535

[16] Lloyd, A.C. and Cackette, T.A. (2001) Diesel Engines: Environmental Impact and Control. Journal of the Air \& Waste Management Association, 51, 809-847. https://doi.org/10.1080/10473289.2001.10464315

[17] Krivoshto, I.N., Richards, J.R., Albertson, T.E., et al. (2008) The Toxicity of Diesel Exhaust: Implications for Primary Care. Journal of the American Board of Family Medicine, 21, 55-62. https://doi.org/10.3122/jabfm.2008.01.070139

[18] Kamenka, A. (2014) Six Tough Topics about Harmonic Distortion and Power Quality Indices in Electric Power Systems. The Schaffner Group, Luterbach.

[19] Fetyan, K. and El Gazzar, D. (2014) Effect of Motor Vibration Problem on the Power Quality of Water Pumping Stations. Water Science, 28, 31-41. https://doi.org/10.1016/j.wsj.2014.05.001

[20] Blooming, T.M. and Carnovale, D.J. (2006) Application of IEEE Std 519-1992 Harmonic Limits. Conference Record of 2006 Annual Pulp and Paper Industry Technical Conference, Appleton, 18-23 June 2006, 1-9. 